\title{
Study of NiO-GDC material produced by aqueous tape casting
}

Wilson Acchar ${ }^{1}$, Luana Barbosa Cruz ${ }^{1}$, Herval Ramos Paes Junior ${ }^{2}$

\author{
${ }^{1}$ Post-Graduation Program of Science and Materials Engineering, Federal University of Rio Grande do Norte (UFRN), Natal, \\ Brazil \\ ${ }^{2}$ Universidade Estadual Norte-Fluminense-UENF, Rio de Janeiro,Brazil \\ e-mail: wacchar@gmail.com,cruzluana@gmail.com, hervalpaes@gmail.com
}

\begin{abstract}
Studies have been developed in last decades in order to produce NiO-based material to be used as anode in solid oxide fuel cell (SOFC). Aqueous-based tape casting was used to produce NiO-GDC substrates with smooth and homogeneous surfaces and good flexibility. Physical and mechanical properties were obtained in green tapes sintered at temperatures ranging from 1200 to $1400^{\circ} \mathrm{C}$. The tapes sintered in $1400{ }^{\circ} \mathrm{C}$ showed the best density and porosity values and mechanical strength between 7 and $25 \mathrm{MPa}$. SEM micrographs show a dense material with cracks and pores. The sintered material shows the presence of nickel oxide and gadolinium cerium oxide.
\end{abstract}

Keywords: NiO-GDC; sintering; tape casting

\section{INTRODUCTION}

Solid oxide fuel cells (SOFC) are a green and clean energy and have been intensively studied in the last decades. Many studies are developed in order to reduction the operating temperature, fabrication costs and improve the energy efficiency [1-3]. Two basically points were investigated. The first point is to developed new electrolyte material with higher ionic conductivity and the second is to decrease the electrolyte thickness, developing the electrode-supported SOFC [4,5]. GDC electrolyte has an ionic conductivity higher than of yittria stabilized zirconia (YSZ) and a thermal expansion coefficient much closer to that of the Ni-cermet and commercial ferrite stainless interconnects compared to YSZ, making the GDC a very good candidate to electrolyte material [6].

Recently, some works about tape casting and solid-state reaction of NiO-GDC anode substrate have been reported in the literature [6-9]. The mainly result obtained in these studies indicated that is possible to produce a homogeneous anode substrate by tape casting process.

Tape casting has showed to be an excellent good method to obtain thin films and is particularly indicated to produce multilayer ceramic composite and nanostructured material [10-14]. The objective of this work was to obtain a Ni-GDC homogeneous sheet.

In this study, Ni-GDC sheet was produced by an aqueous-based tape casting process and sintered at different temperatures. The physical and mechanical values behavior of sintered material was evaluated.

\section{MATERIALS AND METHODS}

Ni-GDC anode green tapes were obtained by aqueous tape casting. The slurries were prepared with 50 wt. $\%$ NiO-CDG powder. Details about the rheological characterization were reported earlier [9]. The results indicated that the acrylic-based suspensions showed a pseudoplastic behavior and remained stable and homogeneous, which is ideal to tape casting process. Debinding of the green laminates was performed by heating up to $600{ }^{\circ} \mathrm{C}$ with the rate of $5{ }^{\circ} \mathrm{C} \mathrm{min}^{-1}$. Sintering process was carried out in an electric furnace (Nabertherm, Germany) at temperatures between $1200{ }^{\circ} \mathrm{C}$ and $1400{ }^{\circ} \mathrm{C}$ during 1 hour. The apparent density and porosity of the sintered tapes were determined by using the Archimedes water displacement method. Mechanical strength at room temperature of the sintered samples (average of three specimens for each value) were measured with a universal testing machine (Zwick-Roell, $2.5 \mathrm{kN}$ ) in three-point bending tests at a constant cross-head speed of 0.5 $\mathrm{mm} / \mathrm{min}$. The crystalline phases present after sintering were identified by X-ray diffraction (Shimadzu, XRD60). The microstructures of fractured surfaces were examined by Scanning Electron Microscopy (Shimadzu SSX-550,25KV) 


\section{RESULTS AND DISCUSSION}

Figure 1 shows the X-ray diffraction pattern of the green tape sintered at $1400^{\circ} \mathrm{C}$ during 1 hour. The sintered material showed the presence of Nickel oxide and gadolinium cerium oxide, as expected. No others phases or new reaction products were identified. Similar crystalline phases were founded at $1200^{\circ} \mathrm{C}$. The GDC phases founded in this work are totally in agreement with the reported in the literature [10].

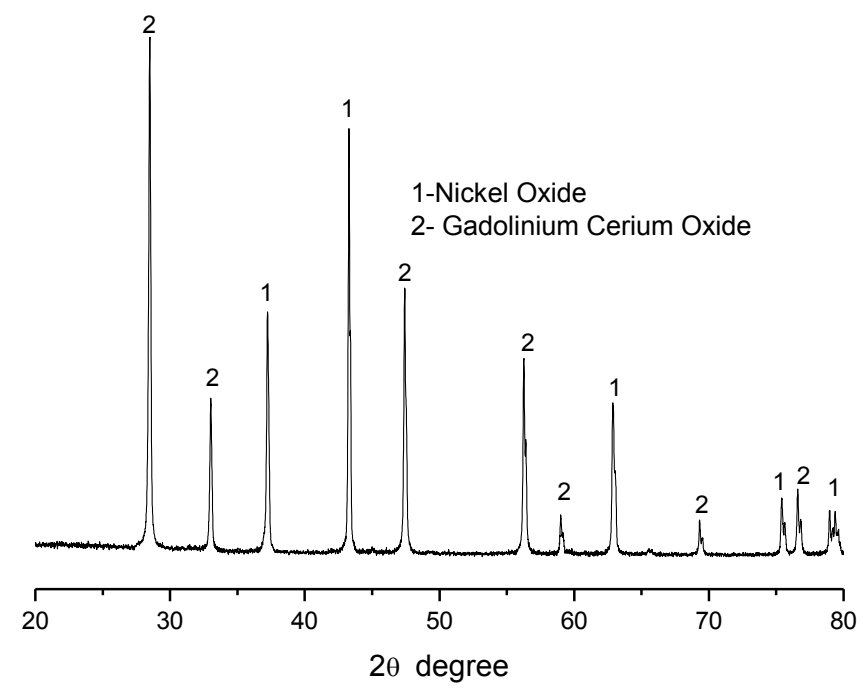

Figure 1: X-ray diffraction of green tape sintered at 1400C.

Figure 2 shows the NiO-GDC sheet obtained after the tape casting process. The tape shows a smooth and homogeneous surface, showing no visible superficial defects.

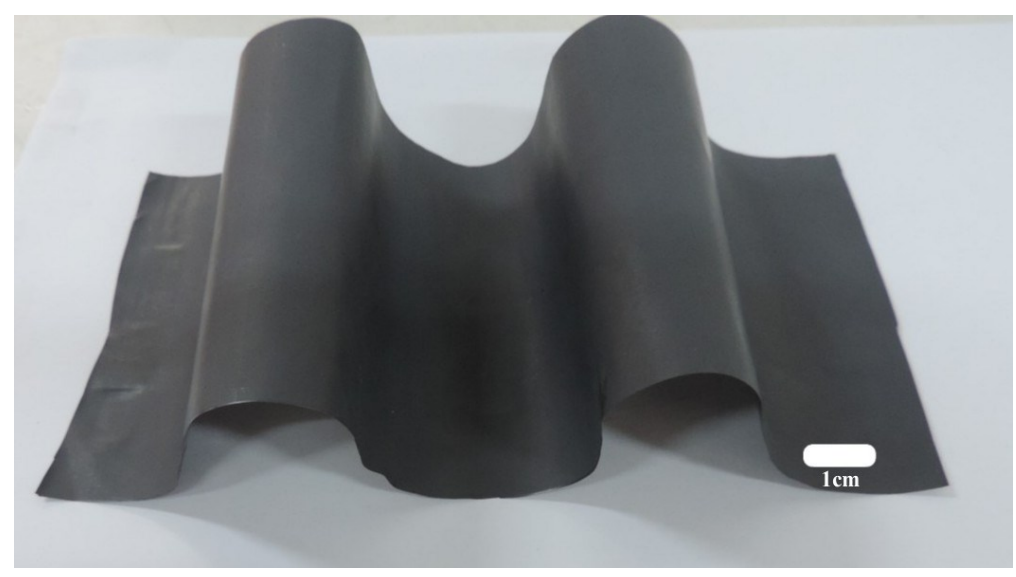

Figure 2: Green tapes.

Figure 3 shows compares the porosity and density values founded in this work with data reported in the literature. The sintered material shows an improvement of density and porosity values by increasing the sintering temperature, as expected. The best values were founded at $1400^{\circ} \mathrm{C}(\mathrm{P}=30 \%, \mathrm{D}=6,5 \mathrm{~g} / \mathrm{cm} 3)$. The density obtained in this work show better density values an as compared to the literature [7], regardless the sintering temperature. Figure 4 shows the strength values of the simple tape and laminates. The multilayer ceramic package (laminates) used in this work were prepared by a thermocompression of three simple tapes at $100 \mathrm{oC}$ with a pressure of $2 \mathrm{MPa}$. The tapes and laminates show a flexural strength of approximately 7 and $25 \mathrm{MPa}$, respectively. The low strength values founded can be related to the processing defects produced in the tape casting technique. The results indicated that the laminates show better strength values as compared to the monolayer tape, demonstrating that the laminates improves the strength of the monolithic layer. Figure 5 shows 
SEM micrographs of the green and sintered tapes. It is possible to see the presence of nickel oxide (gray area) and the gadolinium oxide (white regions), according to the x-ray diffraction (fig. 1).

The sintered material showed a dense structure, but the presence of cracks and pores, which can explain the low strength values of the sheets. Studies are under way in order to improve having a crack free sintered material with better mechanical properties.

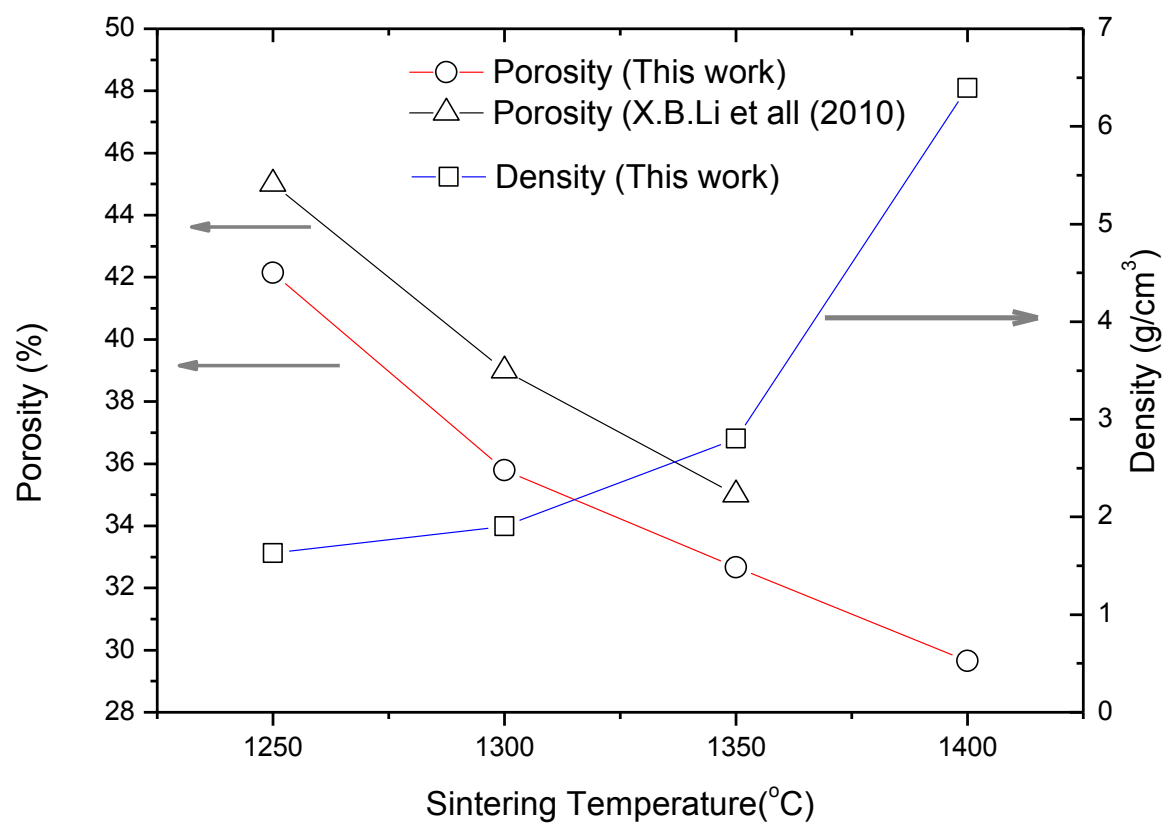

Figure 3: Porosity and density values of the sintered sheets.

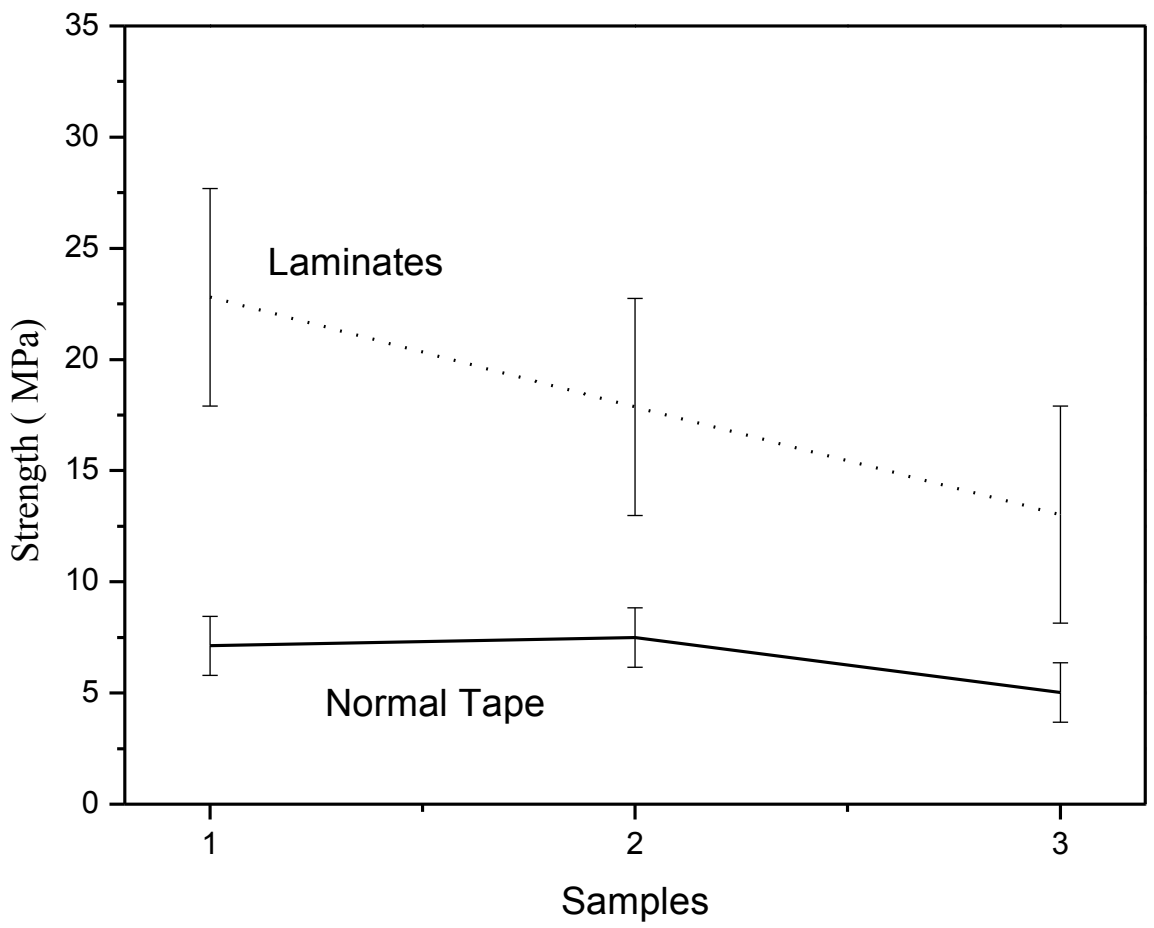

Figure 4: Strength values of normal tapes and laminates. 


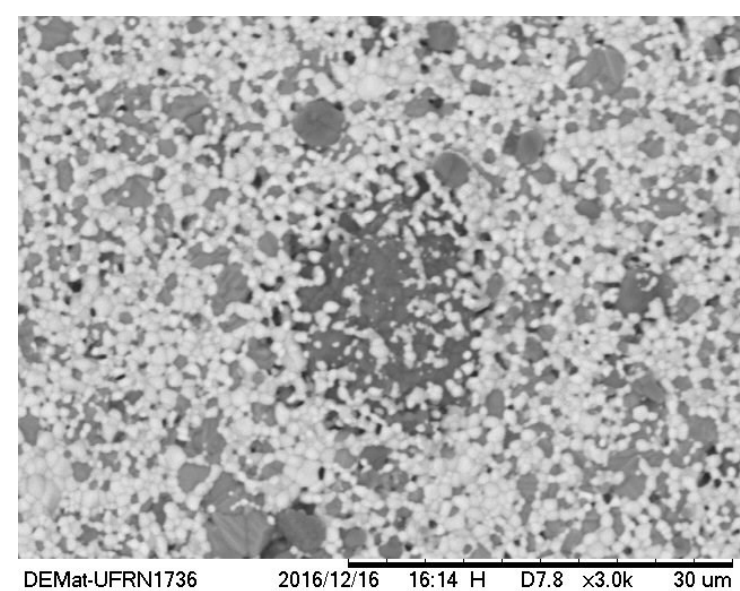

a)

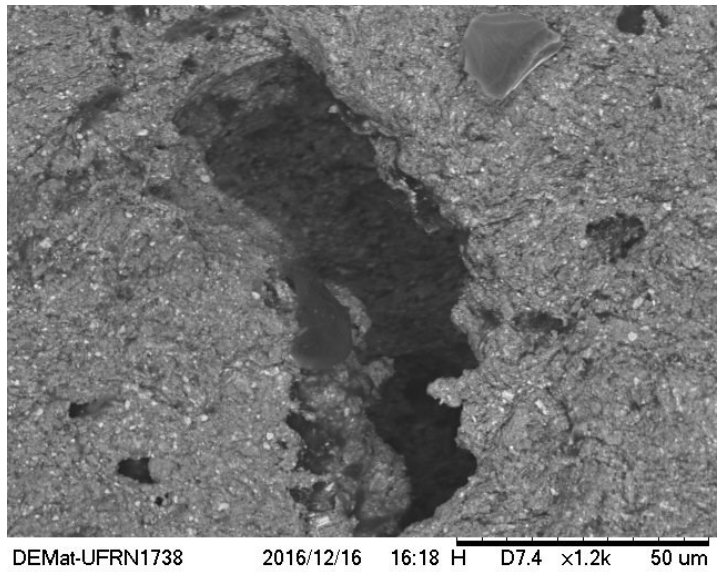

c)

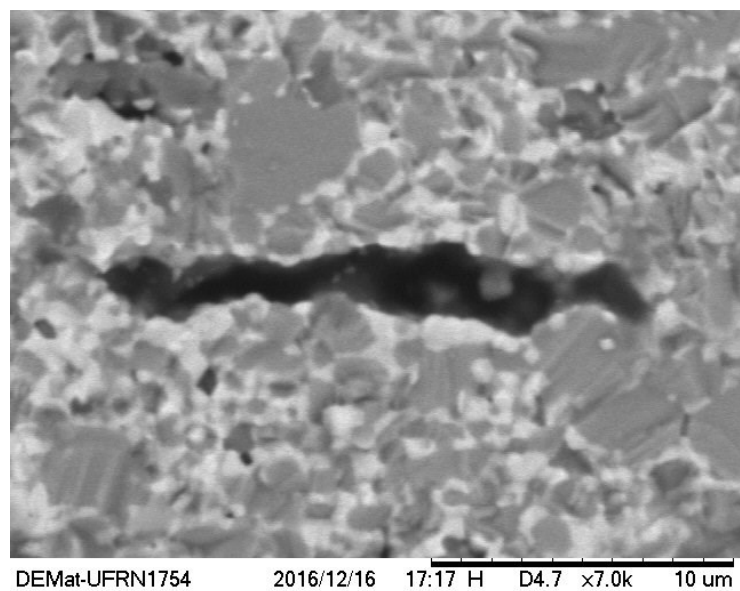

b)

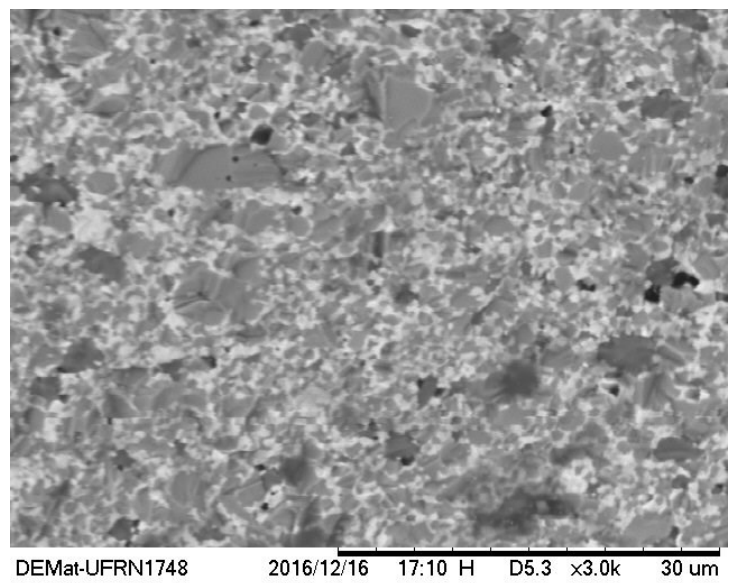

d)

Figure 5: MEV of the sheets (a) green and (b,c,d) sintered.

\section{CONCLUSIONS}

NiO-GDC anode substrates were successfully obtained by aqueous-based tape casting process and sintering. Xray diffraction at the sintered tape showed the presence of nickel oxide and gadolinium cerium oxide. No other crystalline phase was detected. The best sintering temperature was $1400^{\circ} \mathrm{C}$ for $1 \mathrm{~h}$, in which sufficient open porosity of around $30 \%$ was obtained. Mechanical bending strength between 7 (normal tape) and $25 \mathrm{MPa}$ (laminates) were obtained, which can be associated to the presence of cracks and pores. The sintered material showed a dense structure, but the presence of cracks and pores.

\section{ACKNOWLEDGMENTS}

The authors gratefully acknowledge the financial support of CNPq and CAPES.

\section{BIBLIOGRAPHY}

[1] SHAO Z., ZHOU W., ZHU Z., "Advanced synthesis of materials for intermediate temperature SOFC", Progress in Materials Science, v.57, pp. 804-874, 2012.

[2] CHOUDHURY A., CHANDRAHA H., AROSA A., "Application of SOFC technology for power generation-A review”, Renewable and Sustainable Energy reviews, v.20, pp. 430-442, 2013.

[3] COLOGNA M., SGLAVO V.M. "Sintering and deformation of solid oxide fuel cells produced by sequential tape casting”, International Journal Applied Ceramic Technology, v.7, pp. 803-813,2010.

[4] ZHANG Y., GAO J., MENG G., et al., "Production of dense yttria stabilized zirconia thin films by dipcoating for IT-SOFC application”, Journal of Appl Electrochemical, v.34,pp.637-641,2004. 
[5] SINGHAI S.C. “Advances in solid oxide fuel cell technology”, Solid State Ionics, v.135 pp. 305-313,2000.

[6] FU C., CHAN S.H., LIU Q., et al., "Fabrication and evaluation of Ni-GDC composite anode prepared by aqueous-based tape casting method for low-temperature solid oxide fuel cell", Int. J.Hydrogen Energy, v.35,pp. 301-307, 2010.

[7] LI X.B., WANG H.Y., GU H.X., et al., "Preparation of gradient Ni-SDC anode by tape casting and cosintering", Science of Sintering, v. 42, pp.153-159, 2010.

[8] LENG Y.J, CHAN S.H., JIANG S.P., et al.," Low-temperature SOFC with thin film GDC electrolyte prepared in situ by solid-state reaction", Solid State Ionics, v.170, pp. 9-15, 2004.

[9] ACCHAR W, SILVA A.C., CRUZ L.B., et al., "Ni-GDC nano-composite material prepared by aqueous based tape casting", accepted to Materials Science Forum, 2017.

[10] MINATTO F.D., MILAK P., NONI A. Jr, et al., "Multilayered ceramic composites - a review", Advances in Applied Ceramics, v.114, pp.127-138, 2015.

[11] GUGLIELMI, P.O., BLASÉ, D., HABLITZEL, M.P., et al.,"Microstructure and flexural properties of multilayered fiber-reinforced oxide composites fabricated by a novel lamination route", Ceramics International, v.41, pp.7836-7846, 2015.

[12] THOMAS, M., JURGEN, H., GOMES, C.M., et al., "Slurry-based additive manufacturing of ceramics", International Journal of Applied Ceramic Technology, v.12, pp.18-25, 2015.

[13] COLOGNA, M., SGLAVO, V.M., "Sintering and deformation of solid oxide fuel cells produced by sequencial tape casting", International Journal Applied Ceramic Technology, v.7, pp.803-813, 2010.

[14] CORREA, M.A., ARAUJO, M.R., ACCHAR, W., et al, " $\mathrm{ZrO}_{2}$ tape as flexible substrate to artificially nanostructured materials", accepted to Materials Letters, 2017. 